\title{
HUBUNGAN REGULASI EMOSI TERHADAP PENGUNGKAPAN DIRI PENGGUNA TWITTER RENTANG USIA DEWASA AWAL SE-MALANG RAYA
}

\author{
Yudi Suryanto*, Nadiya Andromeda, Sri Wiworo R.I.H.
}

* Corresponding Author:

Universitas Wisnuwardhana Malang Email:

yudi4626@gmail.com

diyasaja@gmail.com

woro.indah68@gmail.com
Abstrak. Penelitian ini bertujuan untuk mengetahui apakah ada pengaruh regulasi
emosi terhadap pengungkapan diri pada pengguna Twitter rentang usia dewasa awal
di Malang. Metodologi yang digunakan kuantitatif korelasional dengan mengguna-
kan analisis deskriptif. Insntrumen yang digunakan adalah skala regulasi emosi dan
dan skala self disclosure. Subjeknya 348 akun pengikut akun Twitter @infomalang
yang diambil menggunakan metode random sampling. Hasil penelitian menun-
jukkan pada kelompok regulasi emosi rendah, semakin stabil regulasi emosi maka
semakin tinggi pengungkapan diri. Pada kelompok regulasi emosi tinggi, semakin
stabil regulasi emosi maka semakin menurun pengungkapan diri pengguna Twitter
rentang usia dewasa awal di Malang.
Kata Kunci: Regulasi Emosi; Pengungkapan Diri; Twitter; Perilaku Media Sosial; Emosi

\begin{abstract}
This study aims to determine whether there is an effect of emotional regulation on self-disclosure in early adulthood Twitter users in Malang. The methodology used is quantitativecorelational by using descriptive analysis. The subjects were 348 accounts of followers of the @infomalang Twitter account which were taken using the random sampling method. The resercher using emotional regulation scale adn self disclosure scale. The results showed that in the low emotion regulation group, the more stable the emotional regulation, the higher self-disclosure. In the high emotional regulation group, the more stable the emotional regulation, the lower the self-disclosure of Twitter users in the early adulthood range in Malang.

Keywords: Emotion Regulation; Self-disclosure; Twitter; Social Media Behavior; Emotions
\end{abstract}

\section{PENDAHULUAN}

Komunikasi menjadi salah satu kegiatan yang tidak bisa lepas dari kehidupan manusia. Melalui komunikasi, orang umumnya menyampaikan apa yang ingin disampaikan dengan tujuan agar orang lain mengerti atau memahami. Perkembangan teknologi informasi telah membawa manusia ke level baru cara berkomunikasi. Salah satunya melalui media sosial. Di media sosial, seseorang dapat mengungkapkan apa saja terkait dengan pendapatnya, pandangannya terhadap sesuatu kejadian, atau juga menampilkan karyanya dengan bebas. Hal yang dibagikan pun beraneka ragam, mulai dari perasaan bahagianya usai wisuda, sampai perasaan sedih setelah ditinggal kekasih. Namun ada beberapa orang yang memilih diam di media sosial. Perbedaan setiap orang dalam menggunakan media sosial ini menjadi salah satu fenomena yang sering dijumpai. Seseorang mungkin akan mengungkapkan isi hatinya ke media sosial karena ada hal yang menurutnya perlu disuarakan atau hanya sekadar mengisi waktu luang. Sementara orang yang lain memilih untuk tidak melakukannya.

Pengungkapan diri menurut Devito (2011) adalah jenis komunikasi di mana individu mengungkapkan informasi tentang dirinya yang mungkin disembunyikan atau tidak diceritakan kepada orang lain yang dilakukan secara 
sadar. Penelitian yang dilakukan oleh Sagiyanto dan Ardiyanti (2018) mengungkap bahwa salah satu bentuk pengungkapan diri seseorang melalui media sosial Instagram adalah dengan mengunggah petikan quote sebagai bentuk dari curahan perasaan, pikiran dan pengalaman hidup. Penelitian lain yang dilakukan oleh Suyadi (2017) menemukan bahwa pengungkapan diri yang dilakukan oleh wanita lebih tinggi dibandingkan dengan pria. Wanita cenderung lebih mudah mengungkapkan isi hatinya melalui media sosial, sedangkan pria lebih cenderung memberikan informasi daripada mengungkapkan perasaan mereka. Jika dikaitkan dengan makna hidup, penelitian yang dilakukan oleh Satrio dan Budiani (2018) kepada mahasiswa jurusan Bahasa Indonesia Universitas Negeri Surabaya, menyatakan bahwa terdapat hubungan antara makna hidup dengan pengungkapan diri. Dimana semakin tinggi pengungkapan diri seseorang maka semakin meningkat pula makna hidupnya. Berlaku juga sebaliknya, semakin tinggi nilai makna hidup seseorang maka semakin tinggi frekuensi pengungkapan dirinya. Penelitian lain menemukan bahwa tipe kepribadian extraversion dan neuroticism memiliki pengaruh yang signifikan terhadap pengungkapan diri pada dewasa awal (Fauzia, Maslihah, \& Ihsan, 2019). Sementara itu, penelitian lain yang dikemukakan oleh Pertiwi (2016), menemukan bahwa terdapat pengaruh yang signifikan kesepian terhadap pengungkapan diri seseorang di media sosial.

Dari beberapa penelitian di atas, dapat diketahui bahwa seseorang menggunakan media sosial sebagai salah satu bentuk pengungkapan dirinya. Namun tidak serta merta apa yang sedang ada di pikirannya kemudian diungkapkan ke media sosial. Pada kenyataannya, terjadi sebuah proses pemikiran dan juga pertimbangan mengenai apa saja yang seharusnya seseorang unggah di media sosial. Seseorang mungkin saja memikirkan dampak yang bisa timbul akibat unggahannya, apakah unggahannya akan menyakiti orang lain, apakah unggahannya akan bermanfaat untuk orang lain, apakah unggahannya perlu diketahui orang lain, apakah kegiatan yang sedang dia lakukan perlu dilihat orang lain dan juga pertimbangan-pertimbangan lainnya. Tak jarang dalam mengungkapkan isi hatinya di media sosial, seseorang melibatkan perasaan dan emosi yang dialami.

Semua orang merasakan dan mengalami emosi. Baik itu emosi positif maupun negatif, masing-masing orang dan setiap hari. Emosi adalah hal yang normal kita jumpai setiap hari. Emosi dapat berupa perasaan sedih, merasa bersalah, marah, menyalahkan diri sendiri, rendah diri, frustrasi, senang, kagum dan lain sebagainya. Seseorang membutuhkan pengelolaan emosi yang baik sebelum mengunggah sesuatu ke media sosial. Usaha untuk mengatur atau mengelola emosi yang dapat mempengaruhi perilaku individu untuk mencapai tujuannya disebut dengan regulasi emosi (Balter, dalam Silaen dan Dewi, 2015). Regulasi emosi adalah istilah yang umumnya digunakan untuk menggambarkan kemampuan seseorang untuk secara efektif mengelola dan merespons pengalaman emosional. Orang-orang secara tidak sadar menggunakan strategi pengaturan emosi untuk menghadapi situasi sulit berkali-kali sepanjang hari. Sebagian besar dari kita menggunakan berbagai strategi pengaturan emosi dan dapat menerapkannya pada situasi yang berbeda untuk beradaptasi dengan tuntutan lingkungan kita.

Regulasi emosi menurut Leahy dkk (2011) dapat diartikan sebagai strategi untuk mengatasi emosi yang bermasalah dan mal adaptif yang digunakan individu ketika dihadapkan dengan intensitas emosi yang tidak diinginkan. Seseorang harus mampu menjaga emosi dalam batasan normal sehingga tidak menimbulkan emosi yang terlalu berlebihan.

Penelitian yang dilakukan Carysa (2019) menemukan bahwa regulasi emosi memiliki pengaruh jika dikaitkan dengan agresivitas pada atlet sepak bola di usia remaja. Di mana semakin tinggi tingkat regulasi emosi sang atlet, maka semakin rendah agresivitas atlet sepak bola tersebut. Penelitian oleh Handayani (2018) menyatakan bahwa bentuk dari regulasi emosi pengguna media sosial antara lain menggunakan pertimbangan, logika dan pemikiran matang untuk mengurangi resiko. Mereka cenderung mempunyai perasaan dan pikiran negatif ketika mengalami kegagalan namun dapat berperilaku positif meskipun menyalahkan diri sendiri, melakukan perbandingan diri dengan pengguna media sosial lain, dan lebih sering merasakan emosi negatif setelah menggunakan media sosial.

Rolston (2016) mengungkapkan bahwa emosi, pikiran dan perilaku saling berhubungan. Ketika suatu peristiwa terjadi, maka akan me- 
munculkan emosi yang akan seseorang rasakan, kemudian emosi ini akan mempengaruhi pikiran dan perilaku orang tersebut. Apabila emosi orang tersebut negatif maka kemungkinan akan menimbulkan pikiran dan perilaku yang negatif juga. Sedangkan jika emosi yang timbul adalah emosi yang positif, maka berkemungkinan juga akan menghasilkan pikiran dan perilaku yang positif.

Contoh kasus terjadi di Banda Aceh yang dikutip dari okezone.com, seorang pria menyebarkan foto bugil tunangannya ke media sosial karena kecewa, belakangan hubungan keduanya renggang dan jalinan cinta putus di tengah jalan sebelum bersanding di pelaminan. Kasus ini dapat dijadikan bukti bahwa terdapat adanya pengaruh emosi yang kemudian mempengaruhi pikiran dan perilaku seseorang seperti yang dikemukakan oleh Rolston di atas. Bentuk emosi pada pelaku adalah kekecewaan kemudian perilaku berpikir dengan menyebarkan foto bugil sang kekasih, maka akan membuat keadaan menjadi lebih baik dan perilaku menyebarkan foto pun akhirnya muncul.

Dalam kehidupan sehari-hari, sadar ataupun tidak sadar, seseorang akan melakukan pengungkapan dirinya. Salah satu media yang digunakan seseorang dalam mengungkapkan dirinya adalah melalui media sosial. Banyak sekali media sosial yang ada di era teknologi seperti sekarang. Mulai dari Facebook, Twitter, Instagram, Pinterest, Ello, Google+ dan masih banyak yang lainnya. Twitter menjadi salah satu media sosial populer yang sampai sekarang masih sering digunakan oleh banyak kalangan. Seorang pengguna Twitter dapat mengunggah unggahan (yang kemudian disebut tweet) berupa teks, foto dan juga video dengan batasan sebanyak 280 karakter huruf. Isi tweet seseorang pun beraneka ragam, mulai interaksi sosial, pengungkapan isi hati, pengungkapan karya, membagikan berita dan lain sebagainya. Namun satu yang menarik dan membedakan dengan media sosial populer lainnya adalah adanya fitur Trending, berisi daftar isu yang saat itu sedang ramai dibicarakan oleh pengguna dalam periode waktu tertentu, dan semua pengguna diperbolehkan untuk ikut meramaikannya.

Data yang dihimpun dari Oberlo.com mengatakan ada 330 juta pengguna aktif Twitter setiap bulannya dan 134 juta pengguna aktif setiap harinya. Jumlah tweet dalam sehari menca- pai 500 ribu tweet yang berarti bahwa ada 5.787 tweet per detik di seluruh dunia. Hal ini menjadi salah satu bentuk kepopuleran Twitter sekarang. Masih menurut data yang sama, terdapat 63\% pengguna twitter didominasi oleh laki-laki sedangkan sisanya adalah perempuan. Sebanyak $66 \%$ pengguna Twitter berada di rentang usia 35-60 tahun.

Ada beberapa alasan yang menjadi pertimbangan seseorang lebih suka bermain Twitter dibandingkan dengan media sosial yang lain. Beberapa alasannya antara lain karena Twitter pada dasarnya berbasis teks, sehingga penggunanya diharuskan dapat menggunakan kalimat seefektif mungkin agar dapat dipahami oleh orang lain, kemudian kebanyakan penggunanya diisi oleh kalangan-kalangan akademisi. Kebijakan timeline twitter juga menjadi sarana membagikan informasi dengan cepat, jadi lebih efektif dalam membagikan informasi seperti berita ataupun kabar lainnya. Fitur reply di twitter memungkinkan penggunanya untuk saling menanggapi dan terkadang menjadi tempat diskusi terkait isu tertentu. Tidak jarang, beberapa konten viral berasal dari media sosial berlogo burung biru ini.

Khusus di Indonesia, data yang dikeluarkan oleh datareportal.com pada bulan Januari 2019 mengungkap bahwa Twitter menjadi media sosial paling sering digunakan di nomor empat setelah YouTube, Facebook dan Instagram. Total penggunanya mencapai 6,46 juta dengan prosentase sebanyak $65 \%$ laki-laki dan $35 \%$ perempuan. Kebanyakan pengguna Twitter laki-laki dan perempuan berada di rentang usia 18-34 tahun. Di mana usia tersebut adalah usia seseorang yang sedang duduk di bangku sekolah, umumnya di universitas.

Menjamurnya universitas di Malang, Jawa Timur membuat banyak mahasiswa datang ke kota ini setiap tahunnya, jumlahnya mungkin lebih dari ribuan mahasiswa baru. Tidak dipungkiri sebagian besar mereka juga pasti mengenal teknologi dan internet sehingga menggunakan media sosial khususnya Twitter.

Rentang usia pengguna Twitter jika dikaitkan dengan teori dalam ilmu psikologi, maka masuk dalam rentang usia dewasa awal yang diungkapkan oleh Hurlock (1986). Rentang usia dewasa awal adalah mulai dari 18 hingga 40 tahun. Pada masa dewasa awal ini, terjadi peralihan pandangan dari egosentris menjadi empati. 
Sehingga secara umum seseorang sudah mampu meregulasi emosinya dengan baik. Dengan regulasi emosi yang baik, harusnya seseorang di masa dewasa awal lebih bijak dalam mengungkapkan dirinya melalui media sosial.

Namun fenomena yang dijumpai, penulis melihat pengguna media sosial khususnya Twitter lebih bebas dalam mengungkapkan perasaannya, sehingga peneliti tertarik untuk meneliti fenomena tersebut dikaitkan dengan regulasi emosi. Penelitian ini kemudian diberi judul "Pengaruh regulasi emosi terhadap pengungkapan diri pada pengguna Twitter rentang usia dewasa awal di Malang".

Berdasarkan yang sudah dijelaskan di atas, peneliti akan meneliti apakah ada pengaruh regulasi emosi terhadap pengungkapan diri pada pengguna Twitter rentang usia dewasa awal?. Penelitian ini bertujuan untuk mengetahui pengaruh regulasi emosi terhadap pengungkapan diri pada pengguna Twitter rentang usia dewasa awal di Malang.

Manfaat penelitian secara teoritis, diharapkan dapat bermanfaat untuk menambah wawasan ilmu pengetahuan dalam bidang psikologi sosial dan klinis. Terutama mengenai konsep regulasi emosi dalam mempengaruhi pengungkapan diri. Penelitian ini diharapkan dapat memberikan sumbangan kajian mengenai pengaruh regulasi emosi terhadap pengungkapan diri dilihat dari sudut pandang dewasa awal pengguna media sosial Twitter. Manfaat praktis penelitian ini adalah dapat dijadikan bahan pertimbangan sebagai pemahaman dan pengetahuan yang mendasar menanggapi pengaruh regulasi emosi terhadap pengungkapan diri pengguna media sosial terutama pengguna Twitter. Hal ini dapat digunakan sebagai upaya pencegahan dan intervensi terkait masalah-masalah yang dapat timbul akibat penggunaan media sosial. Dengan ini, penggunaan media sosial Twitter diharapkan tidak melanggar hak-hak orang lain maupun melanggar Undang-undang Informasi dan Transaksi Elektronik (UU ITE).

Selain itu, penelitian ini diharapkan dapat memberikan pemahaman bahwa sebelum menyampaikan sesuatu ke media sosial membutuhkan banyak pertimbangan. Hendaknya seseorang lebih berhati-hati dan memilah-milah kalimat yang akan digunakan. Sehingga tidak merugikan diri sendiri atau pun orang lain.

\section{METODE}

Metode penelitian dalam penelitina iniadalah menggunakadesain kuantitaif korelasional. Terdapat 2 varibael yang menjadi obyek pengukuran yaitu:

1. (Y) Pengungkapan diri adalah kegiatan yang dilakukan individu dewasa awal dalam membagikan informasi kepada orang lain melalui media sosial Twitter yang didasari dengan tujuan, jumlah dan frekuensi tertentu, serta sifat, keakuratan dan kedalaman dari informasi yang diungkapkan.

2. (X) Regulasi Emosi adalah kemampuan individu usia dewasa awal dalam menilai, mengatasi, mengelola serta mengekspresikan emosinya melalui pemilihan situasi, modifikasi situasi, penyebaran perhatian, perubahan kognitif dan perubahan respon.

Populasi dalam penelitian ini adalah pengguna media sosial Twitter di Malang. Untuk memudahkan dalam mengetahui lokasi pengguna Twitter yang akan digunakan sebagai populasi dari penelitian ini, maka penulis menggunakan pengikut di akun Twitter @infomalang yang jumlahnya sebanyak 383.369 pengikut yang diakses pada tanggal 20 Januari 2020 pukul 13.52 WIB. Dari jumlah ini, ada sebesar $66 \%$ pengikut akun Twitter yang diketahui berusia antara 2036 tahun atau sebanyak 253.024 akun. Dengan ini, maka populasi yang digunakan dalam penelitian ini adalah sebanyak 253.024 akun Twitter pengikut @infomalang.

Penulis menggunakan sampel penelitian dari jumlah pengikut akun Twitter @infomalang rentang usia dewasa awal. Untuk menentukan jumlah sampel yang akan digunakan dalam penelitian, penulis menggunakan metode sampel random sampling dan menggunakan penentuan jumlah sampel dalam tabel Isaac dan Michael (Latipah, 2014). Berdasarkan tabel tersebut, maka ukuran sampel minimal dalam penelitian ini ditetapkan dengan taraf kesalahan 5\% (derajat kepercayaan 95\%) dan diperoleh ukuran sampel sebesar 348 sampel akun pengikut akun Twitter@infomalang.

Teknik pengumpulan data dilakukan peneliti untuk memperoleh dan mengumpulkan data. Adapun instrumen penelitian yang digunakan dalam penelitian ini adalah angket atau kuesioner. Metode pengumpulan data dalam penelitian ini adalah menggunakan skala Likert. Dalam penelitian ini, penulis menggunakan 
empat alternatif jawaban, yaitu: sangat setuju (SS), setuju (S), tidak setuju (TS), dan sangat tidak setuju (STS). Skala Likert ini terdiri dari pernyataan favourable dan un-favourable. Pernyataan tersebut berkaitan dengan obyek sikap yang akan diungkap, sehingga pernyataan favourable merupakan pernyataan yang berisi halhal positif sedangkan pernyataan un-favourable merupakan pernyataan yang berisi hal-hal negatif yang bertentangan atau tidak mendukung ciri perilaku atau obyek sikap yang ingin diungkap.

\section{Skala Pengungkapan Diri}

Dalam penelitian ini, peneliti mengadaptasi dimensi pengungkapan diri Wheeless dan Grotz (Bitna Kim dkk, 2015) dan memodifikasinya agar sesuai dengan konteks media sosial. Wheeless dan Grotz menemukan bahwa pengungkapan diri bersifat multidimensi dan mereka menemukan lima dimensi pengungkapan diri yang di antaranya adalah; niat untuk mengungkapkan, jumlah pengungkapan, sifat positif-negatif dari pengungkapan, kejujuran-akurasi pengungkapan, dan kontrol umum pengungkapan.

Tabel 1. Blueprint Pengungkapan Diri

\begin{tabular}{lc}
\hline Dimensi & Jumlah Item \\
\hline Intent to disclose (Niat) & 12 \\
Amount (Jumlah) & 8 \\
Valensi & 8 \\
Kejujuran & 8 \\
Kedalaman & 9 \\
Total & $\mathbf{4 5}$ \\
\hline
\end{tabular}

Skala kemudian dikelompokkan dalam pernyataan favourable dan unfavourable dengan 4 alternatif jawaban, yakni: Sangat Setuju (SS), Setuju (S), Tidak Setuju (TS), Sangat Tidak Setuju (STS). Skor item bergerak dari angka 1 sampai 4. Untuk setiap pernyataan, subjek akan diberikan nilai sesuai dengan skala kategori jawaban yang diberikan dengan penilaian sebagai berikut:

Tabel 2. Skoring Pengungkapan Diri

\begin{tabular}{lcc}
\hline Alternatif & fav & unfav \\
\hline SS : Sangat Setuju & 4 & 1 \\
S : Setuju & 3 & 2 \\
TS : Tidak Setuju & 2 & 3 \\
STS: Sangat Tidak Setuju & 1 & 4 \\
\hline
\end{tabular}

Wahyu Widiarso (2010) menyatakan bahwa apabila menggunakan 5 alternatif jawaban, maka responden cenderung memiliki alternatif jawaban yang ada di tengah, karena dirasa paling aman, mudah, dan tidak perlu pemikiran yang rumit. Maka disarankan alternatif jawaban hanya 4 saja. Sehingga skala Pengungkapan Diri yang diberikan pada subjek dalam penelitian ini menggunakan 4 alternatif jawaban dengan tujuan menghilangkan jawaban ragu-ragu.

\section{Uji Validitas Pengungkapan Diri}

Dalam penelitian ini, peneliti langsung menyebarkan kuesioner. Penyebaran kuesioner ini dilakukan secara online melalui google form. Adapun prosesnya yaitu menggunakan sampel pengguna Twitter pengikut akun @infomalang sesuai dengan sampel yang digunakan dalam penelitian ini yakni sebanyak 348 akun.

Untuk menghitung validitas skala Pengungkapan Diri, digunakan bantuan komputasi SPSS20. Valid tidaknya suatu item instrument dapat diketahui dengan membandingkan indeks korelasi Product Moment Pearson dengan level signifikansi 5\% sebagai nilai kritisnya. Apabila koefisien validitas kurang daripada 0,30 biasanya dianggap sebagai tidak memuaskan, Azwar (2015). Hasil penghitungan validitas tiap butir item disajikan dalam tabel berikut ini:

Tabel 3. Hasil uji validitas pengukuran Pengungkapan Diri putaran ke-5

\begin{tabular}{lll}
\hline & $\begin{array}{l}\text { Corrected Item-Total } \\
\text { Correlation }\end{array}$ & $\begin{array}{l}\text { Cronbach's Alpha } \\
\text { if Item Deleted }\end{array}$ \\
\hline Y1 & 0,315 & 0,878 \\
Y2 & 0,377 & 0,876 \\
Y9 & 0,37 & 0,877 \\
Y13 & 0,543 & 0,871 \\
Y14 & 0,531 & 0,871 \\
Y17 & 0,581 & 0,87 \\
Y18 & 0,397 & 0,875 \\
Y20 & 0,318 & 0,878 \\
Y21 & 0,586 & 0,87 \\
Y23 & 0,497 & 0,872 \\
Y24 & 0,386 & 0,876 \\
Y25 & 0,583 & 0,87 \\
Y26 & 0,566 & 0,871 \\
Y28 & 0,399 & 0,876 \\
Y29 & 0,67 & 0,868 \\
Y39 & 0,385 & 0,876 \\
Y40 & 0,472 & 0,873 \\
Y41 & 0,484 & 0,873 \\
Y42 & 0,549 & 0,871 \\
Y43 & 0,539 & 0,871 \\
Y44 & 0,365 & 0,877 \\
Y45 & 0,393 & 0,876 \\
\hline
\end{tabular}


Setelah uji coba sebanyak lima kali putaran dilakukan, terdapat total 23 item yang gugur. Pada putaran pertama 20 item gugur $(5,6,7,8$, 10, 11, 12, 15, 16, 22, 27, 30, 31, 32, 33, 34, 35, 36, 37, dan 38.), Pada putaran kedua terdapat 1 item gugur (3), pada putaran ketiga terdapat 1 item gugur (19), pada putaran keempat ada 1 item gugur (4) dan tidak ada item gugur di putaran kelima. Dari sisa item yang valid, maka dibuatlah blueprint Pengungkapan Diri hasil uji coba seperti di tabel berikut:

Tabel 4. Blueprint Skala Pengungkapan Diri

\begin{tabular}{lc}
\hline Dimensi & Jumlah item \\
\hline Intent to disclose (Niat) & 3 \\
Amount (Jumlah) & 5 \\
Valensi & 6 \\
Kejujuran & 1 \\
Kedalaman & 7 \\
Total & $\mathbf{2 2}$ \\
\hline
\end{tabular}

\section{Reliabilitas Skala Pengungkapan Diri}

Reliabilitas merupakan konsistensi atau kestabilan skor suatu instrumen penelitian terhadap individu yang sama, dan diberikan dalam waktu yang berbeda (Muri Yusuf, 2014). Metode yang digunakan untuk menguji kehandalan atau reliabilitas adalah Alpha Cronbach. Suatu instrumen dikatakan reliabel apabila hasil Alpha Cronbach > 0,6 menurut Guilford dalam (Nasrah, Jasruddin, \& Tawil, 2017). Penghitungan reliabilitas skala Pengungkapan Diri dilakukan dengan menggunakan bantuan komputer Seri Program Statistik (SPSS-20).

Tabel 5. Reliabilitas Statistik skala Pengungkapan Diri

\begin{tabular}{ll}
\hline Cronbach's Alpha & N of Item \\
\hline, 878 & 22 \\
\hline
\end{tabular}

Tabel 6. Interpretasi Koefisien Reliabilitas Guilford

\begin{tabular}{ll}
\hline Interval & Koefisien Kategori \\
\hline $0,00-0,19$ & Sangat rendah \\
$0,20-0,39$ & Rendah \\
$0,40-0,59$ & Sedang \\
$0,60-0,79$ & Tinggi \\
$0,80-1,00$ & Sangat tinggi \\
\hline
\end{tabular}

Dari penghitungan reliabilitas skala Pengungkapan Diri, diperoleh hasil koefisien Alpha Cronbach sebesar 0,878 , di mana nilai tersebut lebih besar dari 0,8. Dengan ini, skala Pengungkapan Diri dapat dinyatakan sangat reliabel.

\section{Skala Regulasi Emosi}

Skala Regulasi Emosi disusun oleh peneliti sendiri dengan mengacu pada proses regulasi emosi yang dikemukakan oleh Gross (2007) yang menjabarkan proses regulasi emosi menjadi lima proses. Skala ini terdiri dari beberapa item, dengan empat pilihan jawaban yaitu; SS (Sangat Setuju), S (Setuju), TS (Tidak Setuju), dan STS (Sangat Tidak Setuju). Adapun blueprint skala Regulasi Emosi dapat dilihat pada table berikut:

Tabel 7. Blueprint Regulasi Emosi

\begin{tabular}{ll}
\hline Aspek & Jumlah \\
\hline Pemilihan situasi & 4 \\
Modifikasi situasi & 4 \\
Penyebaran atensi & 4 \\
Perubahan kognitif & 4 \\
Perubahan respon & 4 \\
Total & $\mathbf{2 0}$ \\
\hline
\end{tabular}

Skala kemudian dikelompokkan dalam pernyataan favourable dan unfavourable dengan 4 alternatif jawaban, yakni: Sangat Setuju (SS), Setuju (S), Tidak Setuju (TS), Sangat Tidak Setuju (STS). Skor item bergerak dari angka 1 sampai 4. Untuk setiap pernyataan, subjek akan diberikan nilai sesuai dengan skala kategori jawaban yang diberikan dengan penilaian sebagai berikut:

Tabel 8. Skoring Regulasi Emosi

\begin{tabular}{lcc}
\hline Alternatif & fav & unfav \\
\hline SS : Sangat Setuju & 4 & 1 \\
S : Setuju & 3 & 2 \\
TS : Tidak Setuju & 2 & 3 \\
STS: Sangat Tidak Setuju & 1 & 4 \\
\hline
\end{tabular}

Wahyu Widhiarso (2010) menyatakan bahwa apabila menggunakan 5 alternatif jawaban, maka responden cenderung memiliki alternatif jawaban yang ada di tengah, karena dirasa paling aman, mudah, dan tidak perlu pemikiran yang rumit. Maka disarankan alternatif jawaban hanya 4 saja. Sehingga skala Regulasi Emosi yang diberikan pada subjek dalam penelitian ini menggunakan 4 alternatif jawaban dengan tujuan menghilangkan jawaban ragu-ragu.

\section{Uji Validitas Regulasi Emosi}

Dalam penelitian ini, peneliti langsung menyebarkan kuesioner. Penyebaran kuesioner ini dilakukan secara online melalui google form. Adapun prosesnya yaitu menggunakan sampel pengguna Twitter pengikut akun @infomalang 
sesuai dengan sampel yang digunakan dalam penelitian ini yakni sebanyak 248 akun.

Untuk menghitung validitas skala Regulasi Emosi, digunakan bantuan komputasi SPSS20. Valid tidaknya suatu item instrument dapat diketahui dengan membandingkan indeks korelasi Product Moment Pearson dengan level signifikansi 5\% sebagai nilai kritisnya. Apabila koefisien validitas kurang daripada 0,30 biasanya dianggap sebagai tidak memuaskan, Azwar (2015). Hasil penghitungan validitas tiap butir item disajikan dalam tabel berikut ini:

Tabel 9. Hasil Penghitungan Validitas Skala Regulasi Emosi Putaran ke-2

\begin{tabular}{lll}
\hline & $\begin{array}{l}\text { Corrected Item-Total } \\
\text { Correlation }\end{array}$ & $\begin{array}{l}\text { Cronbach's Alpha } \\
\text { if Item Deleted }\end{array}$ \\
\hline X2 & 0,542 & 0,651 \\
X4 & 0,489 & 0,667 \\
X14 & 0,433 & 0,685 \\
X15 & 0,483 & 0,669 \\
X17 & 0,437 & 0,683 \\
X20 & 0,320 & 0,716 \\
\hline
\end{tabular}

Setelah dilakukan uji coba sebanyak tiga kali, terdapat 14 pernyataan yang tidak valid dan dinyatakan gugur $(1,3,5,6,7,8,9,10,11,12$, 13, 16, 18 dan 19), sehingga tersisa 6 pernyataan yang valid. Kemudian dibuatkan blueprint Regulasi Emosi hasil uji coba seperti pada tabel berikut.

Tabel 10. Blueprint Regulasi Emosi

\begin{tabular}{lc}
\hline Aspek & Jumlah \\
\hline Pemilihan situasi & 2 \\
Modifikasi situasi & - \\
Penyebaran atensi & - \\
Perubahab kognitif & 2 \\
Perubahan Respon & 2 \\
Total & $\mathbf{6}$ \\
\hline
\end{tabular}

\section{Reliabilitas Skala Regulasi Emosi}

Reliabilitas perlu dilakukan untuk mengetahui bahwa yang diuji coba kehandalannya hanyalah nomor pernyataan yang sahih saja. Metode yang biasa digunakan untuk uji reliabilitas adalah Alpha. Suatu instrumen dikatakan reliabel apabila hasil Alpha Cronbach > 0,6 menurut Guilford dalam (Nasrah, Jasruddin, \& Tawil, 2017). Penghitungan reliabilitas skala Regulasi Emosi dilakukan dengan menggunakan bantuan SPSS. Hasil reliabilitas skala Regulasi Emosi disajikan dalam tabel berikut ini:
Tabel 11. Reliabilitas Statistik skala Regulasi Emosi

\begin{tabular}{ll}
\hline Cronbach's Alpha & N of Item \\
\hline, 718 & 6 \\
\hline
\end{tabular}

Tabel 12. Interpretasi Koefisien Reliabilitas Guilford

\begin{tabular}{ll}
\hline Interval & Koefisien Kategori \\
\hline $0,00-0,19$ & Sangat rendah \\
$0,20-0,39$ & Rendah \\
$0,40-0,59$ & Sedang \\
$0,60-0,79$ & Tinggi \\
$0,80-1,00$ & Sangat tinggi \\
\hline
\end{tabular}

Dari hasil perhitungan reliabilitas skala Regulasi Emosi pada uji coba, diperoleh hasil koefisien Alpha Cronbach sebesar 0,718, dimana nilai tersebut lebih besar dari 0,6 . Sehingga skala Regulasi Emosi peneliti memiliki tingkat reliabilitas yang tinggi.

\section{Teknik Analisis Data}

Analisis data yang diperoleh adalah data yang bersifat kuantitatif, yaitu berupa angka-angka, sehingga analisisnya menggunakan teknik statistik. Teknik analisis data yang digunakan untuk mengetahui Pengaruh Regulasi Emosi terhadap Pengungkapan Diri Dewasa Awal Pengguna Twitter di Malang adalah menggunakan deskriptif korelasional dengan rumus uji korelasi Product Moment Pearson.

\section{Uji Hipotesis}

Data yang diperoleh adalah data yang bersifat kuantitatif, dan penelitian ini berfokus pada mencari korelasi atau hubungan. Sehingga analisis data yang digunakan untuk menguji hipotesis adalah dengan uji analisis regresi linear sederhana (Winarsunu, 2015).

\section{Uji Analisis Deskriptif}

Menurut (Azwar, 2010) analisis deskriptif data dapat memberikan gambaran penting mengenai distribusi skor skala pada kelompok subjek yang dikenai pengukuran dan berfungsi sebagai informasi mengenai keadaan subjek pada aspek atau variabel yang diteliti. Analisis deskriptif penelitian lakukan untuk mengetahui seberapa besar tingkat Regulasi Emosi dan Pengungkapan diri yang terjadi pada pengguna twitter di Malang rentang usia dewasa awal.

Analisis deskriptif juga digunakan untuk mengetahui faktor/aspek manakah yang menjadi penyumbang terbesar Regulasi Emosi dan 
Pengungkapan Diri yang kemudian oleh peneliti juga dilakukan untuk membuat saran. Analisis deskriptif faktor/aspek dapat dilakukan dengan membandingkan nilai rata-rata tiap faktor/aspek, sedangkan untuk mengetahui seberapa besar data tingkat keadaan subjek dapat diketahui dengan menghitung distribusi frekuensi.

Distribusi frekuensi yang dipakai menggunakan kategorisasi berdasarkan distribusi normal, dimana subjek digolongkan ke dalam tiga kriteria seperti pada tabel berikut. Distribusi frekuensi yang digunakan menggunakan kategorisasi berdasarkan model distribusi normal. Pengelolaan subjek menjadi tiga kriteria sebagai berikut:

Tabel 13. Pengelolaan Kriteria Analisis Berdasarkan Mean Teoritis

\begin{tabular}{lll}
\hline Variabel & Interval & Kriteria \\
\hline Pengungkapan & $\begin{array}{l}\mathrm{X} \leq(\mathrm{M}-1,0 \mathrm{e}) \\
\text { Diri }\end{array}$ & $\begin{array}{l}\text { Rendah } \\
\text { (M-1,0e } \leq \mathrm{X}<\end{array}$ \\
& $\mathrm{M}+1,0 \mathrm{e})$ & Sedang \\
& $(\mathrm{M}+1,0 \mathrm{e}) \leq \mathrm{X}$ & Tinggi \\
Regulasi Emosi & $\mathrm{X} \leq(\mathrm{M}-1,0 \mathrm{e})$ & Baik \\
& $(\mathrm{M}-1,0 \mathrm{e}) \leq \mathrm{X}<($ Cukup \\
& $\mathrm{M}+1,0 \mathrm{e})$ & \\
& $(\mathrm{M}+1,0 \mathrm{e}) \leq \mathrm{X}$ & Kurang \\
\hline
\end{tabular}

Deskripsi data di atas memberikan gambaran penting mengenai distribusi skor skala pada kelompok subjek yang dikenai pengukuran dan berfungsi sebagai informasi mengenai keadaan subjek atau variabel yang diteliti (Azwar, 2010). Selanjutnya peneliti melakukan analisa deskriptif faktor/aspek. Analisa deskriptif faktor/ aspek digunakan untuk mengetahui faktor atau aspek manakah yang menjadi penyumbang terbesar subjek Regulasi Emosi dan Pengungkapan Diri yang kemudian oleh peneliti juga dilakukan untuk membuat saran. Analisa deskriptif faktor/aspek dapat dilakukan dengan membandingkan nilai rata- rata tiap faktor/ aspek atau mean teoritis dengan cara total skor tiap aspek dibagi jumlah subjek (Azwar, 2010).

\section{HASIL DAN PEMBAHASAN Hasil}

Uji Normalitas

Tujuan diadakan uji normalitas adalah untuk mengetahui data yang dimiliki masing-masing variabel penelitian terdistribusi normal atau tidak. Hasil perhitungan SPSS for windows versi
20 untuk uji normalitas adalah sebagai berikut:

Tabel 14. Uji Normalitas

\begin{tabular}{lll}
\hline \multicolumn{2}{c}{ One-Sample Kolmogorov-Smirnov Test } \\
\hline & & Unstandardized \\
& Residual \\
$\mathrm{N}$ & 348 \\
Normal Parame- & Mean &, 0000000 \\
tersa,b & Std. Deviation & 10,60016330 \\
& Absolute &, 058 \\
& Positive &, 058 \\
& Negative &,- 040 \\
Kolmogor- & & 1,086 \\
ov-Smirnov Z & & \\
Asymp. Sig. & &, 189 \\
(2-tailed) & & \\
\hline
\end{tabular}

Sebaran normalitas jika dilihat dari tabel di atas, dapat diketahui jika nilai perhitungan yang dilakukan ternyata harga Kolmogorov-Smirnov $Z$ yang diperoleh adalah 1,086 dan harga $p$ atau Asymp. Sig (2-tailed) $=0,189$. Karena harga $p=$ $0,189>0,05$ maka data penelitian terdistribusi normal.

\section{Uji Linearitas}

Uji linearitas dilakukan untuk mengetahui apakah hubungan masing-masing variabel bersifat linear. Hasil perhitungan SPSS for Windows Versi 20 untuk uji linearitas terdapat pada lampiran. Hasil uji linearitas dapat dilihat pada tabel berikut ini:

Tabel 15. Uji Linearitas

\begin{tabular}{llll}
\hline & & F & Sig. \\
\hline Pengung- & (Combined) & 5,066 &, 000 \\
kapan Diri & Linearity &, 399 &, 528 \\
* Regulasi & Deviation & 5,196 &, 000 \\
Emosi & from Linear- & \\
& ity & \\
\hline
\end{tabular}

Berdasarkan hasil uji linearitas di atas, diketahui nilai sig., Deviation from Linearity sebesar $0,000<0,05$, dan nilai sig. Linearity sebesar 0,528 >0,05, maka dapat disimpulkan bahwa hubungan antara Regulasi Emosi dan Pengungkapan Diri adalah tidak linear. Selanjutnya dilakukan uji asumsi untuk mengetahui pola hubungan antar variabel. Jika ditemukan data non linear untuk analisis pengaruh maka digunakan analisis regresi non linear (Widhiarso: 2011). Regulasi emosi ke dalam kelompok rendah dan tinggi berdasarkan rerata untuk dilakukan uji hipotesis. Hasil rerata variabel regulasi emosi dapat dilihat pada tabel berikut: 
Tabel 17. Nilai rerata variabel Regulasi Emosi

\begin{tabular}{lll}
\hline $\mathrm{N}$ & Valid & 348 \\
& Missing & 0 \\
Mean & & 44,80 \\
Median & & 54,50 \\
Mode & 53 \\
Sum & 15592 \\
\hline
\end{tabular}

Dari tabel di atas, diketahui bahwa nilai rerata atau mean variabel regulasi emosi adalah sebesar 44,80 .

\section{Uji Hipotesis}

Hipotesis merupakan jawaban sementara atas masalah yang dirumuskan. Hipotesis ini harus di uji kebenarannya secara empiris. Hipotesis alternatif (Ha) yaitu hipotesis yang menyatakan ada pengaruh antara satu variabel dengan variabel yang lainnya. Sebelum dilakukan analisis statistik untuk pembuktian hipotesis alternatif yang diajukan maka perlu diajukan hipotesis alternatifnya. Berikut hasil uji korelasi Product Moment Pearson antara variabel Regulasi Emosi dan Pengungkapan Diri dengan membagi variabel prediktor menjadi dua kelompok yakni tinggi dan rendah berdasarkan nilai rata-rata.

Tabel 18. Hasil uji hipotesis dengan korelasi Product Moment

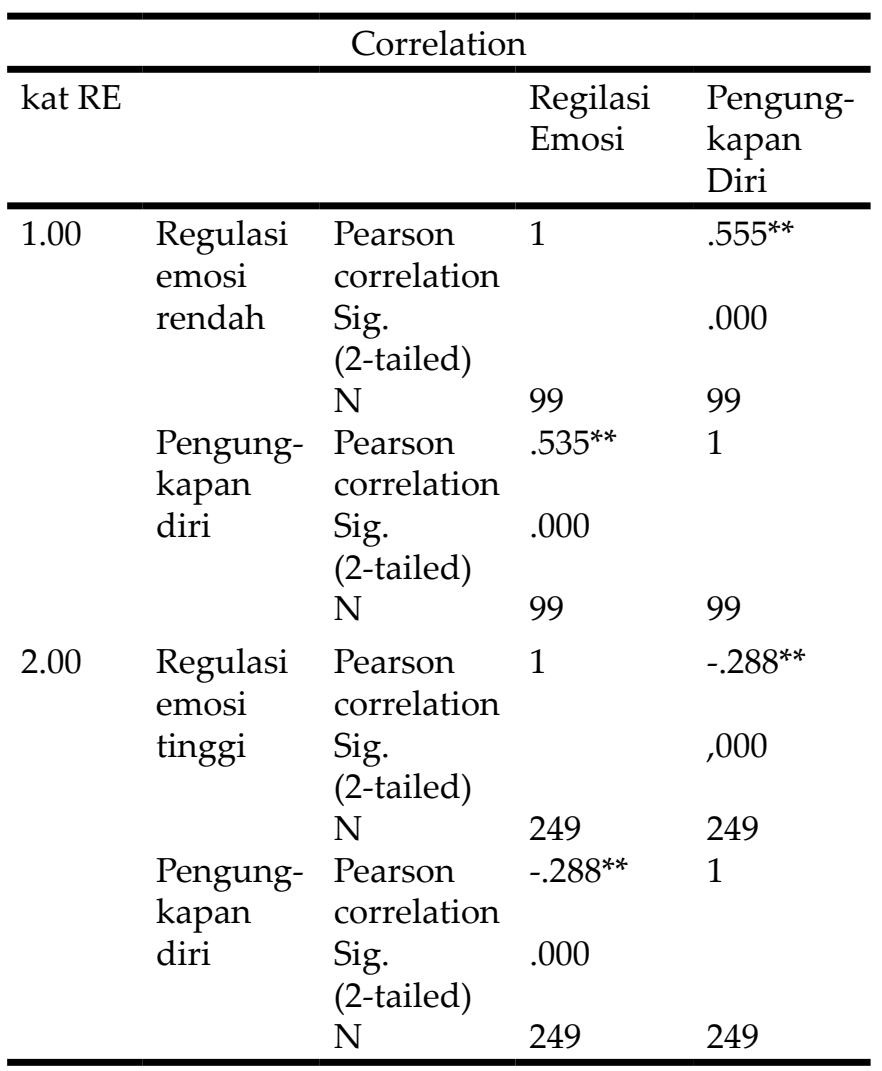

** Correlation is significant at the 0.01 level (2-tailed)
Berdasarkan dari Pearson Correlation di atas, pada kelompok Regulasi Emosi Rendah (kat_RE 1) diketahui nilainya sebesar 0,535. Pada kelompok ini terdapat hubungan yang positif. Artinya pada pada kelompok Regulasi Emosi Rendah, ketika Regulasi Emosi stabil maka intensitas Pengungkapan Diri akan tinggi.

Sedangkan nilai Pearson Correlation pada kelompok Regulasi Emosi Tinggi (kat_RE 2) sebesar -0.288. Pada kelompok ini terdapat hubungan yang negatif. Artinya, pada kelompok Regulasi Emosi Tinggi, maka semakin stabil Regulasi Emosi seseorang maka semakin rendah intensitas Pengungkapan Diri. Dengan ini maka baik H0 maupun Ha dalam penelitian ditolak.

Tabel 19. Uji Korelasi Pearson Regulasi Emosi terhadap Pengungkapan Diri dengan Pengelompokan Data Tinggi dan Rendah Menggunakan Anareg

\begin{tabular}{llllll}
\hline Kat_RE & Model & $\mathrm{R}$ & $\begin{array}{l}\mathrm{R} \\
\text { Square }\end{array}$ & $\begin{array}{l}\text { Adjust- } \\
\text { ed R } \\
\text { Square }\end{array}$ & $\begin{array}{l}\text { Std } \\
\text { Error of } \\
\text { the Es- } \\
\text { timate }\end{array}$ \\
\hline 1.00 & 1 & $.535^{\mathrm{b}}$ & .287 & .279 & 8.940 \\
\hline 2.00 & 1 & $.288^{\mathrm{b}}$ & .083 & .079 & 10.219 \\
\hline
\end{tabular}

a. Predictors: (Constant), Regulasi Emosi

b. Dependent Variable: Pengungkapan Diri

Melihat tabel 19, bahwa koefisien determinan R Square Kelompok Regulasi Emosi Rendah (kat_RE 1) terhadap Pengungkapan Diri sebesar 0,287 yang berarti bahwa sumbangan efektif variabel Kelompok Regulasi Emosi Rendah terhadap Pengungkapan Diri sebesar 28,7\%. Sedangkan determinan R Square Kelompok Regulasi Emosi Tinggi (kat_RE 2) terhadap Pengungkapan Diri sebesar 0.083 yang berarti bahwa sumbangan efektif variabel Kelompok Regulasi Emosi Tinggi terhadap Pengungkapan Diri sebesar $8,3 \%$ sisanya dipengaruhi oleh faktor lain yang tidak diteliti dalam penelitian ini. Dengan demikian, hasil penelitian ini menjadi sebuah temuan bahwa pengguna Twitter rentang usia dewasa awal di Malang memiliki ciri khas yang berbeda dari asumsi awal. Ternyata perbedaan individu dan faktor-faktor lain bisa mempengaruhi pengungkapan diri seseorang, dan media sosial Twitter belum tentu menjadi sebuah media yang digunakan untuk mengekspresikan keterampilan dalam meregulasi emosi. 
Analisis Deskriptif Statistik

Analisis deskriptif data dapat memberikan gambaran penting mengenai distribusi skor skala pada kelompok subjek yang dikenai pengukuran dan berfungsi sebagai informasi mengenai keadaan subjek pada aspek atau variabel yang diteliti (Azwar 2010). Analisis ini dalam penelitian dilakukan untuk mengetahui seberapa besar tingkat Regulasi Emosi dan Pengungkapan Diri yang terjadi pada pengguna Twitter di Malang dengan rentang usia dewasa awal. Selanjutnya, analisis deskriptif ini juga bisa digunakan untuk mengetahui faktor/aspek apa yang menjadi penyumbang terbesar subjek mengalami Regulasi Emosi dan Pengungkapan Diri yang kemudian oleh peneliti akan digunakan dalam pembuatan saran. Analisis deskriptif faktor/aspek dapat dilakukan dengan membandingkan nilai rata-rata tiap faktor/aspek, sedangkan untuk mengetahui sebesar data tingkat keadaan subjek dapat diketahui dengan menghitung distribusi frekuensi. Distribusi frekuensi yang dipakai menggunakan kategorisasi berdasarkan distribusi normal, dimana subjek digolongkan ke dalam tiga kriteria seperti pada tabel berikut.

Tabel 20. Distribusi Frekuensi Pengungkapan Diri

\begin{tabular}{llllll}
\hline & & Freq & Percent & $\begin{array}{l}\text { Valid } \\
\text { Percent }\end{array}$ & $\begin{array}{l}\text { Cumu- } \\
\text { lative } \\
\text { Percent }\end{array}$ \\
\hline Valid & Tinggi & 87 & 25.0 & 25.0 & 25.0 \\
& Sedang & 185 & 53.2 & 53.2 & 78.2 \\
& Rendah & 76 & 21.8 & 21.8 & 100.0 \\
& Total & $\mathbf{3 4 8}$ & $\mathbf{1 0 0 . 0}$ & $\mathbf{1 0 0 . 0}$ & \\
\hline
\end{tabular}

Hasil sebaran data Pengungkapan Diri pada pengguna Twitter di Malang rentang usia dewasa disajikan dalam diagram berikut:

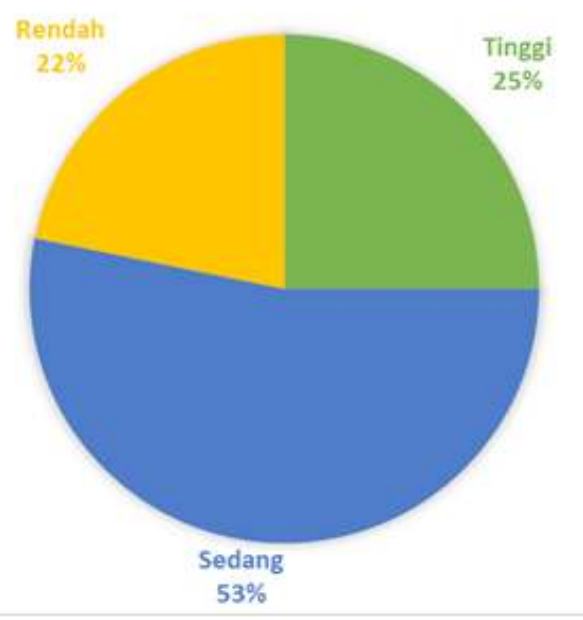

Gambar 1. Distribusi Data Pengungkapan Diri
Berdasarkan gambar di atas maka diketahui bersama bahwa sebagian besar subjek memiliki intensitas Pengungkapan Diri yang sedang. Hal itu ditunjukkan dengan prosentase subjek yang tergolong pada kriteria sedang sebesar 53\% (185 orang). Sementara itu pada kriteria rendah sebesar 22\% (76 orang) dan pada kriteria tinggi sebanyak 25\% (87 orang).

Pengungkapan Diri memiliki 5 aspek dalam penilaiannya, aspek mana yang paling berperan dalam Pengungkapan Diri pengguna Twitter rentang usia dewasa awal di Malang dapat dilihat pada gambar berikut ini:

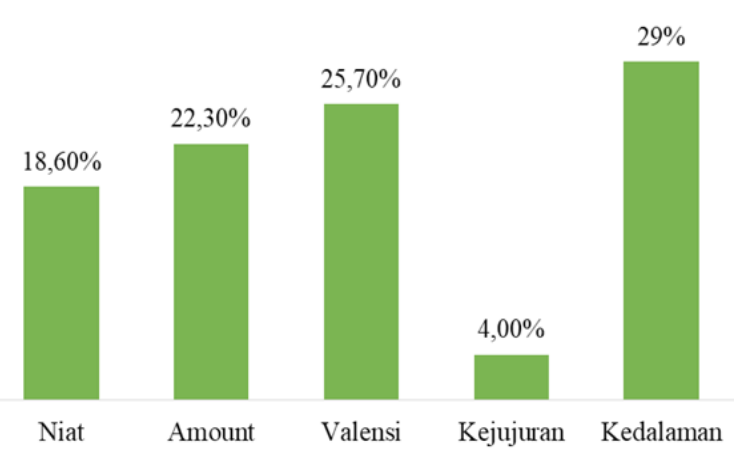

Gambar 2. Analisis Aspek Pengungkapan Diri

Berdasarkan gambar di atas, diketahui bahwa Kedalaman memberikan nilai tertinggi dalam pengungkapan diri yakni sebesar 29,4\%, diikuti dengan Valensi sebesar 25,7\%, Amount sebesar $22.30 \%$, Niat sebesar $18,6 \%$ dan yang terendah adalah Kejujuran sebesar $4 \%$.

Setelah melakukan perhitungan distribusi frekuensi pada variabel regulasi emosi, didapatlah hasil seperti tabel berikut:

Tabel 21. Distribusi Frekuensi Regulasi Emosi

\begin{tabular}{llllll}
\hline & & Freq & Percent & $\begin{array}{l}\text { Valid } \\
\text { Percent }\end{array}$ & $\begin{array}{l}\text { Cumu- } \\
\text { lative } \\
\text { Percent }\end{array}$ \\
\hline Valid & Tinggi & 83 & 23.9 & 23.9 & 23.9 \\
& Sedang & 190 & 54.6 & 54.6 & 78.4 \\
& Rendah & 75 & 21.6 & 21.6 & 100.0 \\
& Total & $\mathbf{3 4 8}$ & $\mathbf{1 0 0 . 0}$ & $\mathbf{1 0 0 . 0}$ & \\
\hline
\end{tabular}

Hasil sebaran data Regulasi Emosi pada pengguna Twitter di Malang rentang usia dewasa awal dalam diagram berikut ini: 


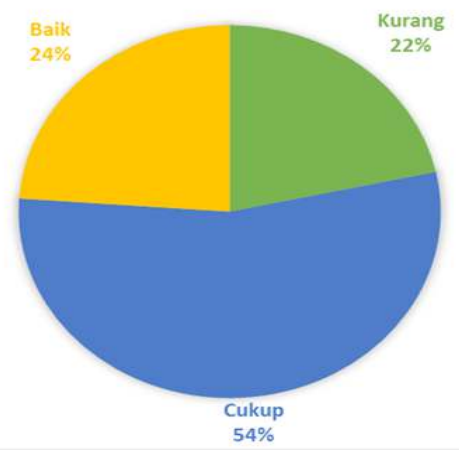

Gambar 3. Sebaran Data Regulasi Emosi

Berdasarkan diagram di atas, maka dapat dilihat bahwa sebagian besar subjek memiliki Regulasi Emosi yang cukup. Hal ini ditunjukkan dengan prosentase subjek yang tergolong pada kriteria kurang sebesar 22\% (75 orang), kriteria cukup sebanyak 54\% (190 orang), dan kriteria baik sebanyak 24\% (83 orang).

Regulasi Emosi memiliki 5 aspek dalam penilaiannya, aspek mana yang paling berperan dalam Regulasi Emosi pengguna Twitter rentang usia dewasa awal di Malang dapat dilihat pada gambar berikut ini:

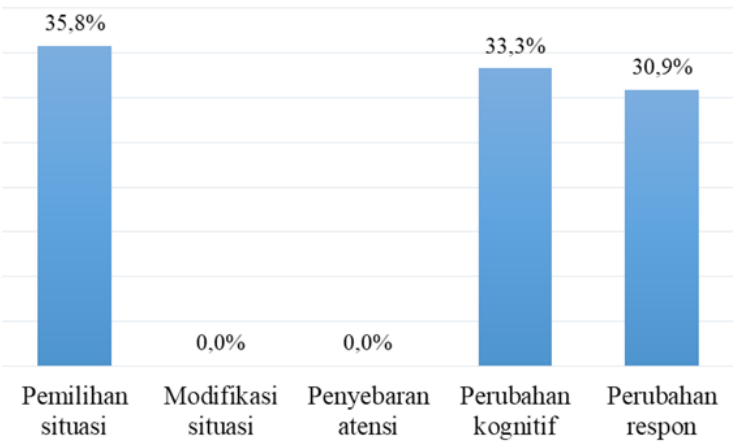

Gambar 4. Analisis Aspek Regulasi Emosi

Dari gambar di atas, diketahui bahwa Pemilihan Situasi memberikan nilai tertinggi pada variabel Regulasi Emosi yakni sebesar $35.8 \%$, disusul dengan Perubahan Kognitif $(33,3 \%)$, dan Perubahan Respon (30,9\%).

\section{Pembahasan}

Berdasarkan penelitian yang sudah dilakukan, diketahui bahwa tidak ada pengaruh regulasi emosi terhadap pengungkapan diri pada pengguna Twitter rentang usia dewasa awal di Malang. Namun terdapat dua kesimpulan yang ditemukan, yakni pada kelompok regulasi emosi rendah, semakin stabil regulasi emosi, semakin meningkat pula pengungkapan dirinya sedangkan pada kelompok regulasi emosi tinggi, semakin stabil regulasi emosi seseorang maka akan semakin berkurang intensitas pengungkapan dirinya ke media sosial Twitter.

Hal ini karena perbedaan individu dan faktor-faktor lain bisa mempengaruhi pengungkapan diri seseorang, dan media sosial Twitter belum tentu menjadi sebuah media yang digunakan untuk mengekspresikan keterampilan meregulasi emosi.

Diketahui jika pengguna cenderung menggunakan Twitter sebagai media pengungkapan diri. Hal ini dapat dilihat di gambar 1 yang menunjukkan bahwa pengguna menggunakan Twitter sebagai metode pengungkapan diri dalam intensitas yang sedang. Dengan ini menandakan bahwa tidak selalu apa yang ada di dalam pikirannya kemudian diungkapkan melalui Twitter. Sejalan dengan penelitian yang dilakukan Handayani (2018), peneliti menemukan bahwa pengguna Twitter mempertimbangkan terlebih dahulu mengenai apa yang akan mereka tulis dan ungkapkan.

Hasil penelitian yang ada pada gambar 3 menunjukkan bahwa kebanyakan pengguna Twitter di Malang mampu meregulasi emosinya secara cukup stabil. Kemudian berdasarkan analisis hasil sumbangan yang diberikan dari variabel regulasi emosi yang dikelompokkan menjadi dua kelompok, diketahui bahwa kelompok regulasi emosi rendah memiliki arah hubungan yang positif. Ketika regulasi emosi semakin stabil, maka pengungkapan diri juga akan semakin meningkat. Sedangkan pada kelompok regulasi tinggi, memiliki arah hubungan yang negatif. Ketika regulasi emosi semakin stabil, maka intensitas pengungkapan diri akan berkurang. Karena seseorang mampu meregulasi emosinya dengan cukup stabil, maka tidak mempengaruhi pengungkapan dirinya.

Pengungkapan diri di Twitter tidak hanya dipengaruhi oleh variabel regulasi emosi, melainkan juga dipengaruhi oleh faktor lain di luar dari penelitian ini. Beberapa faktor lain yang dimaksud seperti variabel kepribadian dan juga kesepian. Orang dengan tipe kepribadian extraversion dan neuroticism cenderung mengungkapkan dirinya ke media sosial (Fauzia, Maslihah, \& Ihsan, 2019). Sementara itu, Pertiwi (2016), menemukan bahwa dewasa awal yang kesepian cenderung mengungkapkan dirinya ke media sosial.

Bollen (2018) yang telah meneliti lebih dari 70.000 akun pengguna Twitter menemukan 
bahwa emosi seseorang cenderung tersentuh setelah membaca atau melihat stimulus seperti gambar atau tulisan dari unggahan orang lain, sedangkan apa yang diungkapkan belum tentu mewakili emosi dari orang tersebut. Dalam penelitian yang sama, agar regulasi emosi seorang pengguna Twitter terukur dengan benar, Bollen melakukan pengukuran regulasi emosi sebelum dan sesudah seseorang nge $\urcorner$-tweet. Selain itu, ditemukan bahwa memang seseorang menggunakan media sosial sebagai media untuk pengungkapan diri, namun bukan menjadi sebuah bentuk ekspresi emosi karena seseorang cenderung menahan diri, menata kalimat yang akan ditulis dan muncul sebuah strategi agar pengguna terlihat rasional dan profesional (Lin, Tov, \& Qiu, 2014). Sejalan dengan ulasan di atas, penelitian lain menemukan bahwa seseorang dengan kemampuan regulasi emosi yang baik cenderung memiliki kelekatan dengan orang lain yang baik juga, kemudian kepercayaan diri mereka akan meningkat sehingga tidak memiliki kesulitan dalam mengungkapkan diri. Dengan ini, mereka juga tidak bergantung dengan media sosial sebagai media untuk mengungkapkan diri (Liu \& Ma, 2019).

Dari ulasan di atas, diketahui bahwa perbedaan individu dalam meregulasi emosinya dapat mempengaruhi pengguna Twitter dalam mengungkapkan dirinya. Pada kelompok regulasi emosi rendah, semakin stabil regulasi emosi maka semakin tinggi pula intensitas pengungkapan diri. Sementara itu, pada kelompok regulasi emosi tinggi, semakin stabil regulasi emosi maka semakin rendah intensitas pengungkapan dirinya. Selain itu pengguna Twitter di Malang rentang usia dewasa awal mengungkapkan diri ke Twitter dalam intensitas sedang. Sementara yang mempengaruhi pengguna Twitter dalam pengungkapan dirinya bukan hanya regulasi emosi melainkan faktor lain yang tidak diteliti dalam penelitian ini.

\section{KESIMPULAN SARAN \\ Kesimpulan}

Berdasarkan analisis yang sudah dilakukan, maka dapat disimpulkan bahwa hipotesis dalam penelitian ini ditolak. Namun terdapat dua kesimpulan yang ditemukan, yakni pada kelompok regulasi emosi rendah, semakin stabil regulasi emosi, semakin meningkat pula pengungkapan dirinya sedangkan pada kelompok regulasi emosi tinggi, semakin stabil regulasi emosi seseorang maka akan semakin berkurang intensitas pengungkapan dirinya ke media sosial Twitter.

Sumbangan kelompok regulasi emosi rendah terhadap pengungkapan diri dalam penelitian ini adalah sebesar $28,7 \%$. Sedangkan sumbangan kelompok regulasi emosi tinggi terhadap pengungkapan diri adalah sebesar $8,3 \%$. Sisanya, pengungkapan diri pengguna Twitter di Malang dipengaruhi oleh faktor lain seperti kepribadian, kesepian, kelekatan dan kepercayaan diri.

\section{Saran}

Berdasarkan hasil penelitian yang telah dilakukan, maka dapat dikemukakan saransaran sebagai berikut:

Saran untuk subjek:

1. Tidak terburu-buru mengungkapkan isi hati ke media sosial.

2. Mempertimbangkan baik dan buruknya isi tulisan yang akan di unggah ke media sosial khususnya Twitter.

3. Sesegera mungkin menyelesaikan masalah agar tidak berdampak pada kondisi psikis.

4. Mengesampingkan emosi negatif sebelum memutuskan sesuatu.

Saran untuk peneliti selanjutnya:

1. Terdapat kelemahan dari teori dan jurnal terdahulu yang digunakan dalam penelitian ini, sehingga peneliti selanjutnya sebaiknya lebih mencermati teori yang akan digunakan.

2. Kelemahan juga terdapat pada indikator dari aspek variabel regulasi emosi yang digunakan untuk membuat alat ukur, peneliti selanjutnya diharapkan lebih cermat lagi dalam menggunakan teori yang akan dipakai dalam penelitian.

3. Mengembangkan variabel penelitian secara berkesinambungan sehingga dapat bermanfaat dan memberikan sumbangan bagi ilmu pengetahuan terutama psikologi sosial dan psikologi klinis khususnya faktor lain yang mempengaruhi regulasi emosi terhadap pengungkapan diri.

\section{REFERENSI}

Azwar, S. (2010). Metode Penelitian. Yogyakarta: Pustaka Pelajar.

Azwar, S. (2012). Reliabilitas dan validitas. Yogyakarta: Pustaka Pelajar. 
Azwar, S. (2015). Penyusunan Skala Psikologi

Bollen, J. (2018). Measuring the effect of expressing your feelings on social media. Diambil kembali dari Behavioural \& Social Sciences: https:// socialsciences. nature.com/users/199233-johanbollen/posts/42357-measuring-the-effects-ofexpressing-your-feeling-on-social-media.

Carysa, Yasinta T. (2019). Pengaruh Regulasi Emosi terhadap Agresivitas Atlet Sepak Bola Usia Remaja. Skripsi. Universitas Sanata Dharma Yogyakarta.

Cheda, Gouraavi. (2019). An explorative study On Social Media and its relationship with Self Esteem and Emotional Regulation. International Journal of Humanities and Social Science Invention (IJHSSI) Volume 8 Issue 03 Ser. II PP.11-18.

Dariyo, Agoes. (2004). Psikologi Perkembangan Dewasa Muda. Jakarta: Grasindo.

Devito JA. 2011. Komunikasi Antarmanusia (5th ed). Tangerang: Karisma Publishing Group.

Fauzia, A. Z., Maslihah, S., \& Ihsan, H. (2019). Pengaruh Tipe Kepribadian terhadap SelfDisclosure pada Dewasa Awal Pengguna Media Sosial Instagram di Bandung. Jurnal Psikologi Sains dan Profesi, 151-160.

Ghozali, \& Imam. (2013). Aplikasi Analisis Multivariate dengan Program IBM SPSS.

Gil, Paul. (2019). What Is Twitter \& How Does It Work? https://www.lifewire.com/whatexactly-is-twitter-2483331 . Diakses pada 18 Des 2019.

Gil, Paul. 2019. What Is Twitter \& How Does It Work? https://www.lifewire.com/what-exactly-istwitter-2483331. Diakses pada18 Des 2019.

Gross. J., J. (2007). Handbook of Emotion Regulation. London: THE GUILFORD RESS New York.

Gross. J.J. (1998). The Emerging Field of Emotion Regulation: An Integrative Review. Educational Publishing Foundation. Vol. 2, No. 5,271-299.

Handayani, Shinta S. (2018). Regulasi Emosi pada Pengguna Media Sosial. Skripsi. Universitas Muhammadiyah Surakarta.

Hurlock, E. B. (1986). PsikoloPerkembangan: suatu pendekatan Rentang. Kehidupan (terjemahaan). Jakarta: Erlangga.

Kemp, Simon. (2019). Digital 2019: Indonesia. https://datareportal.com/https://datareportal. com/reports/digital-2019-indonesia. Diakses pada 9 Desember 2019.

Kurniawan, D. (2008). Tabel Distribusi Dilengkapi Metode untuk Membaca Tabel Distribusi.

Latipah, E. (2014). Metode penelitian Psikologi. Yogyakarta: Deepublish.

Leahy, Robert L. Tirch, Dennis dan Napolitano, Lisa A. (2011). Emotion Regulation in Psychotherapy. London: The Guilford Press. on social networking sites: The role of network. Computers in Human Behavior, 342-350. doi:http://dx.doi.org/10.1016/j.chb.2014.0 9.045

Lin, Ying. (2019). 10 Twitter Statistics Every Marketer Should Know in 2020 [Infographic]. https:// id.oberlo.com/blog /twitter- statistics. Diakses pada 3 Januari 2020.

Liu, C., \& Ma, J.-L. (2019). Adult Attachment Style, Emotion Regulation, and Social Networking Sites Addiction. Front Psychol, 10: 2352.

Mudassir, Saiful. (2017). Astaga! Gara-Gara Gagal Menikah, Pria Ini Sebar Foto Bugil Tunangannya di Medsos. Okezone.com. https://news.okezone.com/read/2017/04/28/ 340/1678787/astaga-gara-gara-gagal-menikahpria-ini-sebar-foto-bugil-tunangannya-dimedsos. Diakses pada 5 November 2019.

Nasrah, Jasruddin, \& Tawil, M. (2017). Pengembangan Perangkat Pembelajaran Fisika Berbasis Pendekatan. Jurnal Pendidikan Fisika Universitas Muhammadiyah Makassar.

Nations, Daniel. (2019). What Is Microblogging?. https://www.lifewire.com/what-ismicroblogging-3486200. Diakses pada 18 Des 2019.

Nyklicek, Ivan, Vingerhoets, Ad \& Zeelenberg, Marcel. (2011). Emotion Regulatin and WellBeing. London: Springer New York Dordrecht Heidelberg.

Pertiwi, W. I. (2016). Pengaruh Kesepian Terhadap Pengungkapan Diri Remaja Di Media Sosial. Psikologi FIP UNJ.

Riswanto, Riswanto. (2016). Penerapan model Problem Based Learning (PBL) Berbantukan Program Adobe flash terhadap kemampuan siswa memecahkan masalah pada materi pokok getaran dan gelombang. Undergraduate thesis, IAIN Palangka Raya.

Rolston, A. dan Richardson, E.L. (2016). What is emotion regulation and how do we do it? Cornell Research Program on Self-injury and Recovery

Sagiyanto, Asriyani \& Nina Ardiyanti. (2018). Self Disclosure melalui Media Sosial Instagram (Studi Kasus pada Anggota Galeri Quote). Nyimak Journal of Communication, 2(1): 81-94.

Santrock, W. John. (2002). Life Span Development: Perkembangan Masa Hidup Ed 5. Jakarta: Erlangga.

Satrio, Hafid P. Budiani, Meita S. (2018). Hubungan Pengungkapan Diri Melalui Media Sosial Instagram Dengan Makna

Schaie, K. W. (1977). Toward a stage theory of adult cognitive development. Aging and human development, 8 , 123-138.

Sears, D.O: Freedman, J.L: Peplau, L.A. (2009). Psikologi Sosial. Ed. 12. Alih Bahasa:

Lin, H., Tov, W., \& Qiu, L. (2014). Emotional disclosure Silaen, Anastasia C. Dewi, Kartika S. (2015). 
Hubungan Antara Regulasi Emosi Dengan Asertivitas (Studi Korelasi pada Siswa di SMA Negeri 9 Semarang). Jurnal Empati, April 2015, Volume 4(2), 175-181.

Suyadi, Astri, Aisyah. (2017). Media sosial dan self disclosure. Jurnal Publikasi. Universitas Muhammadiyah Surakarta.

Thompson, Ross. A. (1994). Emotion Regulation: A Theme in Search of Definition. Monographs of the Society for Research in Child Development. Vol. 59, No. 2/3 25-52

Toomey, Stella T. \& Dorjee, T. (2019). Communicating Across Cultures 2nd Ed. New York: The Guilford Press.

Widhiarso, W. (2011). Belajar Metodologi Penelitian. Diambil kembali dari Data Tidak Linier ? Kita Analisis Secara Terpisah Saja: https:// widhiarso.staff.ugm.ac.id/wp/menyiasatidata-yangtidak-linier/

Widhiarso, W. (2010). Pengembangan Skala Psikologi.

Winarsunu, Tulus. (2015). Statistik dalam Penelitian Psikologi \& Pen-didikan Malang. UMM Press. 